\title{
Diatoms (Bacillariophyceae) from the Bolivian Altiplano: three new araphid species from the Desaguadero River draining Lake Titicaca
}

\author{
Eduardo A. Morales ${ }^{1,2}$, Maria Helena Novais ${ }^{3}$, Gabriela ChÁvez ${ }^{4}$, Lucien \\ HOFFMANN $^{3} \&$ Luc ECTOR $^{3}$ \\ ${ }^{1}$ Herbario Criptogámico, Universidad Católica Boliviana San Pablo, Cochabamba, Bolivia; e-mail: edu. \\ morales2006@gmail.com \\ ${ }^{2}$ Patrick Center for Environmental Research, The Academy of Natural Sciences, Philadelphia, USA \\ ${ }^{3}$ Public Research Centre - Gabriel Lippmann, Department of Environment and Agro-Biotechnologies (EVA), \\ 41 ruedu Brill,L-4422 Belvaux, Luxembourg; e-mail:novais@lippmann.lu,hoffmann@lippmann.lu, ector@ \\ lippmann.lu \\ ${ }^{4}$ Departamento y Carrera de Biología, Universidad Mayor de San Simón, Cochabamba, Bolivia; e-mail: \\ gabita_112terre@hotmail.com
}

\begin{abstract}
Three new araphid diatom species, Pseudostaurosira decipiens E. Morales, G. Chávez et Ector, P. sajamaensis E. Morales et Ector and Staurosira kjotsunarum E. Morales, Novais et Ector are described from a single sample taken from the Desaguadero River in the Bolivian Altiplano. These species clearly belong in their respective genera as evidenced by their morphological features studied using light (LM) and scanning electron microscopy (SEM). Pseudostaurosira decipiens is unique in its genus because of the combination of lanceolate-shaped valves with central area, well-developed spines lacking ligulae, siliceous deposits on outer and inner areolar openings similar to flaps, and the inner rounded structure of the apical pore fields. Pseudostaurosira sajamaensis is different from other species of Pseudostaurosira due to its elliptic to lanceolate valves bearing a wide central sternum, spines with developed ligulae and bilobed flaps, robust volae and reduced or absent apical pore fields. Staurosira kjotsunarum is unique within Staurosira in having elevated costae on both external and internal views, narrowly spatulate spines that hold onto areolae of neighboring valves along a chain, and striae composed of round poroids underneath the apical pore fields on the valve mantle. The three species are compared with morphologically similar taxa and a brief analysis of the richness found in the studied sample in the context of previous publications on diatoms from the Andes and contiguous regions is presented.
\end{abstract}

Key words: Araphids, Bacillariophyceae, biodiversity, diatoms, Pseudostaurosira, South America, sp. nov., Staurosira

\section{Introduction}

Despite the recent publication of treatises on the diatoms from the Andes, the diatom flora of this extensive region in South America remains largely understudied (VAN DE VIJVER \& COCQUYT 2009). Even in zones of similar topography, such as the Altiplano shared by Peru, Bolivia and Chile, aquatic ecosystems can be quite disparate and may host contrasting microorganism assemblages (Patrick 1961; Manguin 1964; Cruces et al. 2006; CABROL et al. 2007; among others). A characteristic region of the Bolivian central Altiplano is the area nearby the inactive Sajama volcano, which hosts a great variety of aquatic ecosystems ranging from wetlands to hypersaline lakes, among lentic habitats, and from small rivulets to wide shallow rivers among lotic environments. These aquatic habitats vary in their degree of impairment due to the presence of small human settlements, where agricultural practices and cattle raising (mainly llamas, sheep and goats) are practiced. Wind and water erosion, aided by human/cattlerelated disturbance, also affects aquatic habitats increasing the concentration of suspended solids, more noticeable in rivers.

A relatively recent publication on Andean diatoms (RUMrICH et al. 2000), based on 350 samples collected randomly from Argentina to Venezuela, suggests that assemblages are 
composed of a high number ( $21 \%$ of a total of 888 recorded taxa) of possible endemics, although a surprising high proportion (42\%) of cosmopolitan taxa, typical of temperate Europe, also exists. The remaining taxa $(63 \%)$ have yet to be studied in more detail to determine their type of distribution. Taxonomically, some taxa presented by RUMRICH et al. (2000) were either new (ca. 9.5\%), possibly new (ca. 6.5\%), or their affinities required a deeper analysis (ca. 30\%). These percentages of new taxa are surprisingly low and do not truly characterize the Andean diatom flora as unique, despite the fact that this area is frequently portrayed as showing a highly varied landscape and a high richness of animals and higher plants (IBISCH \& Merida 2003; Navarro \& Maldonado 2004). Metzeltin \& Lange-Bertalot (1998) and later Lange-Bertalot \& Metzeltin (2009) expressed that the lowlands of South and Central America contain much more characteristic assemblages with only few cosmopolitan representatives. However, the research of the same authors in Andean ecosystems (Rumrich et al. 2000; see also Metzeltin et al. 2005, though for a different set of South American ecosystems) reveals that this observation might be skewed due to sampling of sites showing signs of human-related impairment or located in areas where there is at least some human presence. The possibility that eutrophication and pollution-related problems would tend to facilitate geographic expansion of "weedy" (cosmopolitan) taxa (Kociolek \& Spaulding 2000; MacDougall \& TuRkington 2005; VANORMELINGEN et al. 2008), coupled with more frequent sampling in areas of easy access (near roads, cabin lodges, along touristic trails, etc.), are obvious contributing influences on this skewed view. Given the topographic and geological differences, the relative isolation of sub-basins, coupled with the diversity of types of aquatic habitats present in the Andes, the study of merely 350 samples (RUMRICH et al. 2000) hardly becomes representative of the mosaic of environments in this region of the world.

More attention has been centered on fossil diatoms from paleolakes in regions contiguous to the Sajama volcano (e.g., Servant-VILDARY 1978a; Iltis 1993; Servant \& Servant-Vildary 2003) or in the Uyuni-Coipasa basin (SYLVESTRE et al. 1996, 1999; Sylvestre 2002). The closest sites studied for extant communities of these organisms are further north (Titicaca Lake, e.g., Frenguelli 1939; Servant-VILDARy 1992; TAPIA et al. 2003) or east (Poopó Lake, e.g., ServantVILDARY 1978b; SylveSTRE et al. 2001). However, most of these studies are not based on thorough taxonomical approaches and are now noticeably outdated (Morales et al. 2008). Likewise, investigations on diatoms from the Desaguadero River are centered on the study of fossil/subfossil material (e.g., RigsBy et al. 2005) and there are no studies of the extant diatom flora developing in this river. As part of a first exploration of the diatoms growing near or in Sajama National Park, several epipsammic and epilithic samples were collected from the Desaguadero and Sajama rivers and nearby wetlands and ponds. This manuscript concentrates on three new araphid taxa found in a single sample from the Desaguadero River and it will be later complemented by a broad coverage of the diatom community found in all sampling sites. LM and SEM data for the new taxa are compared and contrasted with reports of morphologically similar diatoms reported from other regions of the world.

\section{Materials and Methods}

The Desaguadero River connects the Bolivian side of Lake Titicaca in the Department of La Paz with Lake Uru-Uru and Lake Poopó in the Department of Oruro, carrying approximately $5 \%$ of the flood water in the Lake Titicaca basin. The site examined for the present study is at $3701 \mathrm{~m}$ a.s.l. and is located at $17^{\circ} 23^{\prime} 51^{\prime \prime} \mathrm{S}$ latitude and $68^{\circ} 14^{\prime} 33^{\prime}$ " W longitude in the Department of Oruro (Fig. 1). The river at this site has a sandy bed and meanders, bifurcates and anastomoses again along a wide river valley. At the time of collection water was brown, visibly charged with suspended solids, had a $\mathrm{pH}$ of 10.4 and a temperature of $7.7^{\circ} \mathrm{C}$. Sediment surface was covered with a brownish greenish film composed of cyanobacteria, chlorophytes, euglenoids and diatoms.

Epipsammon material was collected from the banks of the river at a depth of 20-30 cm absorbing surface sediments with a turkey baster (large plastic pipette) and then poured onto $250 \mathrm{ml}$ plastic bottles. Approximately 20 drops of $40 \%$ formaldehyde were added to the sample to arrest macroinvertebrate activity and diatom cell division. For LM analysis, subsamples of 20-30 ml were placed in beakers and mixed with a similar volume of $70 \%$ nitric acid. The mixture was boiled on a hot plate for $45 \mathrm{~min}$ and repeatedly rinsed ( 8 times) in distilled water. A few drops of the resulting slurry were poured onto coverslips and allowed to dry at room temperature overnight. Permanent slides were mounted with the aid of a hot plate and using Naphrax ${ }^{\odot}$ as mounting medium. Slides were analyzed using a Zeiss 


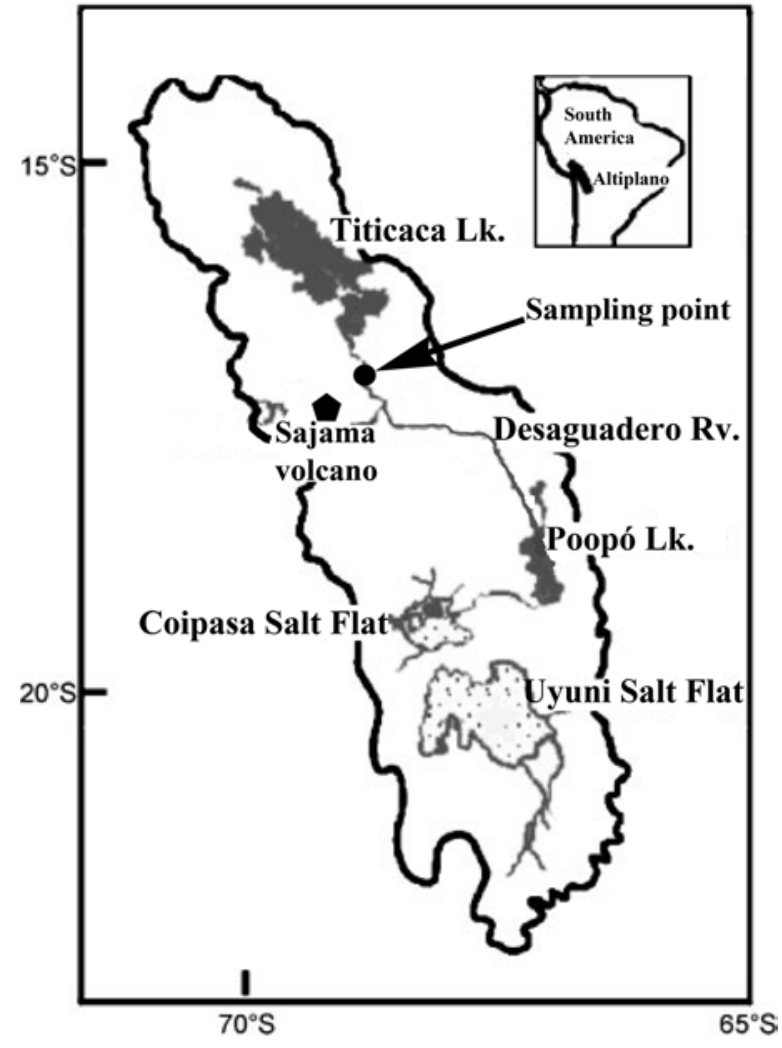

Fig. 1. The South American Altiplano showing the location of Desaguadero River and the sampling point in proximity to the Sajama volcano. The Desaguadero River is shown connecting Lake Titicaca with the saline Lake Poopó and the salt flats of Coipasa and Uyuni, all located in Bolivian territory. Modified from RigsBy et al. (2005).

Universal microscope suited with DIC (Differential Interference Contrast) and a Spot Insight 2 model 18.2 color digital camera. Microphotographs were taken at 2000X using a $2 \mathrm{X}$ optivar and SpotSoftware version 4.6.

For SEM analysis, $2 \mathrm{ml}$ aliquots of clean material were further digested with $100 \mathrm{ml}$ of hydrogen peroxide $(35 \%)$, placing test tubes containing the mixture in hot sand for $36 \mathrm{~h}$, reaching a temperature $210^{\circ} \mathrm{C}$ for at least $24 \mathrm{~h}$ during the process. Preparations were then allowed to settle and the peroxide eliminated by vacuum aspiration. One $\mathrm{ml}$ of hydrochloric acid (37\%) was then added to the samples and allowed to rest for 2-4 h. Samples were rinsed at least three times with distilled water. The material was filtered and rinsed with deionized water through glass fiber filters with a $3 \mu \mathrm{m}$ pore diameter. Coating with platinum was accomplished using a BAL-TEC MED 020 Modular High Vacuum Coating System for $30 \mathrm{~s}$ at $100 \mathrm{~mA}$. A Hitachi SU-70 electron microscope operated at $5 \mathrm{kV}$ and $10 \mathrm{~mm}$ distance was used for the analysis. Micrographs were digitally manipulated and plates containing LM and SEM pictures were mounted using Photoshop CS3.

Identification of taxa was performed using literature published for South America (Metzeltin \& Lange-Bertalot 1998, 2007; Rumrich et al. 2000; Metzeltin et al. 2005). Taxonomic articles by Frenguelli (1939), Patrick (1961), Manguin (1964), Hohn (1966), Servant-Vildary (1986), Morales \& Vis (2007) and Morales et al. (2007) were also used. Additionally, non-South American references were used such as the general floras of PATRICK \& REIMER (1966, 1975), Krammer \& Lange-Bertalot (1986, 1988, 1991a, b), Simonsen (1987), Lange-Bertalot (1993), and HofmANn et al. (2011), as well as references specialized in certain genera such as Navicula (LANGEBertalot 2001), Pinnularia (Krammer 2000) and cymbelloids (KRAMMER 1997a, b).

Descriptions of the new taxa are based on measurements of 30 valves and observation of more than 100 individuals of each taxon under both LM and SEM. Morphological terminology follows ANONYMOUS (1975), Ross et al. (1979) [both references used for terminology applied to striae, areolae and spines], BARBER \& HAWORTH (1981) [for terminology related to valve shape and striae orientation], WILLIAMS \& Round (1987) and Round et al. (1990) [both references used for terminology on areolar substructures, girdle band features and apical pore field characteristics].

\section{Results}

LM and SEM analyses of the sample used during the present study yielded 228 taxa, of which 122 $(53.5 \%)$ could not be identified satisfactorily using the available literature and bear a "cf." or "sp." (undetermined) designation. In some cases, the unknowns had been found during analysis of other samples from other parts of Bolivia and bear a designation using the locality in which they were originally encountered (e.g., Gomphonema sp. 2 PASORAPILLA a taxon originally identified from the Inter-Andean Dry Valleys in the Department of Cochabamba). The 228 taxa belong to 47 genera, $28(59 \%)$ of which contained at least one undetermined taxon. The most specious genera were Nitzschia (33 taxa, 16 undetermined), Navicula (22 taxa, 11 undetermined), Planothidium (16 taxa, 7 undetermined), Caloneis (10 taxa, 9 undetermined), Amphora (10 taxa, 8 undetermined), Gomphonema (10 taxa, 7 undetermined), Pseudostaurosira (10 taxa, 7 undetermined), Ulnaria (9 taxa, 8 undetermined), Encyonema ( 7 taxa, 1 undetermined) and Surirella (7 taxa, 1 undetermined).

Table 1 presents the results of a 500 valve count, which revealed that the sampled community is dominated by Pseudostaurosira 
sajamaensis E. Morales et ECTOR sp. nov. (51.2\%) and Achnanthidium exiguum (GrunOw) CZARNECKI (14.6\%). Pseudostaurosira sp. 2 DESAGUADERO (5\%), Cocconeis placentula var. euglypta (EHRENBERG) GRUNOW (4.6\%) and Gomphonema sp. 2 PASORAPILLA (2.8\%) are also among the most abundant taxa in the sample. The other two taxa described here as new are less frequent: Pseudostaurosira decipiens E. Morales, G. Chávez et Ector sp. nov. (0.6\%) and Staurosira kjotsunarum E. Morales, Novais et ECTOR sp. nov. (0.4\%).

Three of the undetermined fragilarioid species are described below as taxa new to science. Table 2 summarizes the key characteristics of each of these taxa and includes salient features of published morphologically closely related taxa.

\section{Pseudostaurosira decipiens E. Morales, G. CHÁvez et Ector sp. nov. (Figs 2-11: LM; Figs 39-44: SEM)}

Diagnosis: Frustula aspectu cinguli rectangularia superficiei curvata in media parte propter formam lanceolatam valvarum cum area centrali inflata; catenas per spinas conjunctas formantia. Valvae isopolares apicibus rostratis. Longitudo 4-29 $\mu \mathrm{m}$, latitudo 4-6 $\mu \mathrm{m}, 13-15$ striae in $10 \mu \mathrm{m}$. Sternum latum lanceolatum. Limbus valvae abruptus margine parallelo ad juncturam frontis et limbi. Squamae siliceae secus marginem limbi valvae. Striae uniseriatae, 1-2 areolis in fronte valvae, 1-2 areolis in limbo valvae. Areolae rotundae vel ellipticae, transapicaliter elongatae. Volae ramosae, delicatae, margine interiore areolae exorientes. Depositiones siliceae in apertura externa areolae discos natantes formantes. Aperturae interiores areolarum itidem depositionibus siliceis ad instar duorum discorum superpositorum diametris differentis tectae. Spinae solidae spathulatae strias interrumpentes ad juncturam frontis et limbi. Costae non vel leviter elevatae respectu striarum. Areae porellorum in junctura frontis et limbi amborum extremorum valvarum, ex porellos parvos rotundos compositae. Area porellorum externe in valvam depressa, interne itidem depressa, in depressione rotunda characteristica posita. Rimoportula nulla. Fasciae cingulorum apertae sine foraminibus, pars interior conspicue recedens margine limbi valvae, sine fimbriis. Copulae valvarum latiores ceteris elementis limbi. Chloroplasti non visi.

Description: Frustules rectangular in girdle view with curved surface in middle portion due to lanceolate shape of valves with inflated central area; forming chains with the aid of spines (Fig. 11). Valves isopolar, with rostrate apices (Figs 2-10). Length 4-29 $\mu \mathrm{m}$, width 4-6 $\mu \mathrm{m}$, striae density $13-15$ in $10 \mu \mathrm{m}$. Sternum wide, lanceolate. Valve mantle steep with edge parallel to valve face/mantle junction (Figs 2-10, 39-43). Siliceous plaques present along valve mantle edge (Fig. 43). Striae uniseriate, composed of 1-2 areolae on valve face and 1-2 areolae on valve mantle. Areolae round to elliptical (transapically elongated) (Figs 39-42). Volae branched, delicate and arising from the inner edge of each areola (Figs 41, 42). Siliceous depositions on outer areolar opening in the form of rounded floating disks (Figs 39, 42). Inner areolar openings also covered by siliceous depositions in the form of two superimposed disks of different diameter (Figs 40, 44). Spines solid, spatulate, interrupting the striae at the valve face/mantle junction (Figs $39,42,43)$. Costae not raised or only slightly raised with respect to striae (Figs 39, 43). Apical pore fields present on both valve ends at the valve face/mantle junction; composed of small round poroids (Figs 39, 41 partially occluded, 42). Externally, the pore field is sunken into the valve (Fig. 42). Internally, the pore field is also sunken and lies on a characteristically round depression (Fig. 44). Rimoportula absent (Fig. 40). Girdle bands open, without perforations (Fig. 43). Pars interior of valvocopula conspicuously recessed to accommodate valve mantle edge and without fimbriae (not shown). Valvocopula wider than rest of girdle elements (Fig. 43). Plastids not observed.

Holotype: Here designated, permanent slide ANSP GC 26815, Diatom Herbarium, Academy of Natural Sciences, Philadelphia (ANSP). Isotype: Here designated, permanent slide HCUCB D-0246, Herbario Criptogámico Universidad Católica Boliviana, Cochabamba, Bolivia.

Type locality: Desaguadero River, Department of Oruro, Bolivia, Lat. $17^{\circ} 23^{\prime} 51^{\prime \prime}$ S, Long. 68 $14^{\prime} 33^{\prime}$ " W, $3701 \mathrm{~m}$ a.s.l. Collected by G. CHÁVEz, 07-0509.

Etymology: The epithet "decipiens" means "deceiving", referring to the characteristic deposits on the areolar outer and inner surfaces that make this taxon difficult to link with other taxa currently ascribed to Pseudostaurosira. 


\section{Pseudostaurosira sajamaensis E. Morales et ECTOR sp. nov. (Figs 12-26: LM; Figs 45-56: SEM)}

Diagnosis: Frustula aspectu cinguli rectangularia catenas per spinas junctas formantia. Valvae isopolares lanceolatae apicibus rostratis quoad specimina maiora, ellipticae vel rotundae apicibus late rotundatis quoad specimina minora. Longitudo 2-18 $\mu \mathrm{m}$, latitudo 2-4 $\mu \mathrm{m}$, striae 10-14 in $10 \mu \mathrm{m}$. Sternum amplum lanceolatum. Frons valvae gradatim in limbum transiens. Margo limbi valvaris parallela ad juncturam frontis et limbi. Squamae siliceae secus marginem limbi valvae. Striae uniseriatae, 1-2 areolis in fronte valvae, 1-2 areolis in limbo valvae. Areolae rotundae vel trapezoideae transapicaliter elongatae. Volae robustae margine interiore areolae exorientes. Spinae solidae spathulatae strias interrumpentes ad juncturam frontis et limbi. Ligulae bene evolutae, spinarum basibus insertae, nonnunquam aperturam integram areolae contiguae tegentes. Squamae siliceae bilobatae, e basi quoque spinae exorientes, in valvae limbo nonnunquam aperturam integram areolae tegentes, etiam ex margine interiore areolarum nullis spinis contingentium exorientes. Areae porellorum nullae vel leviter evolutae, ex usque duos rotundos porellos formatae. Rimoportula nulla. Fasciae cingulorum apertae sine foraminibus, pars interior conspicue recedens margine limbi valvae, sine fimbriis. Chloroplasti non visi.

Description: Frustules rectangular in girdle view, forming chains with the aid of spines (Fig. 26). Valves isopolar, lanceolate with rostrate apices in larger specimens and elliptical to rounded with broadly rounded ends in smaller representatives (Figs 12-25). Length $2-18 \mu \mathrm{m}$, width $2-4 \mu \mathrm{m}$, striae density $10-14$ in $10 \mu \mathrm{m}$. Sternum wide, lanceolate (Figs 12-25). Gradual transition between valve face and valve mantle (Figs 45, 48, 50, 51-54). Valve mantle edge parallel to valve face/mantle junction (Figs 45, 47, 49, 50, 54-56). Siliceous plaques present along valve mantle edge (Figs 45 , $47,49,54-56$ ). Striae uniseriate, composed of 1-2 areolae on valve face and $1-2$ areolae on valve mantle (Figs 45, 48-50, 51-56). Areolae round or trapezoid (transapically elongated, Figs 48, 51). Volae robust and arising from the inner periphery of each areola (Figs 48-50, 51, 54-56). Spines solid, spatulate, located along each stria at the valve face/mantle junction (Figs 45-56). Welldeveloped ligulae are present at the base of spines and may cover the entire opening of contiguous areolae on valve mantle (Figs 45, 46, 50, 55, 56).
Bilobed siliceous coverings or flaps are produced from the base of each spine at the valve mantle and may cover entire areolar opening (Figs 45, 50, 51-53). Flaps may also be produced from the inner periphery in areolae not contiguous to spines (Fig. 45). Apical pore fields absent or weakly developed, composed of no more than 2 round poroids (Figs 45 occluded, 50 partially occluded). Rimoportula absent. Girdle bands open, without perforations (Figs 49, 55). Pars interior of valvocopula conspicuously recessed to accommodate valve mantle edge and without fimbriae (Fig. 49). Plastids not observed.

Holotype: Here designated, permanent slide ANSP GC 26815, Diatom Herbarium, Academy of Natural Sciences, Philadelphia (ANSP).

Isotype: Here designated, permanent slide HCUCB D-0246, Herbario Criptogámico Universidad Católica Boliviana, Cochabamba, Bolivia.

Type locality: Desaguadero River, Department of Oruro, Bolivia, Lat. $17^{\circ} 23^{\prime} 51^{\prime \prime}$ S Long. 68 $14^{\prime} 33^{\prime \prime}$ W, $3701 \mathrm{~m}$ a.s.l. Collected by G. CHÁvez, 07-0509.

Etymology: The term "sajamaensis" refers to the Sajama volcano in the Department of Oruro, Bolivia.

\section{Staurosira kjotsunarum E. Morales, Novais et ECTOR sp. nov. (Figs 27-38: LM; Figs 57-62: SEM)}

Diagnosis: Frustula aspectu cinguli rectangularia catenas per spinas coniunctas formantes. Valvae isopolares ellipticae apicibus late rotundatis. Longitudo 5-7 $\mu \mathrm{m}$, latitudo $4 \mu \mathrm{m}$, striae 14-16 in $10 \mu \mathrm{m}$. Sternum lineare vel anguste lanceolatum. Limbus abruptus, margine in parte centrali valvae profundiore quam in apicibus. Striae parallelae vel radiatae, uniseriatae, ex aliquot areolis continuo currentibus ab fronte ad limbum. Striae in apicibus valvae infra apicalem aream porellorum in diversis evolutionibus. Areolae ellipticae apicaliter elongatae. Volae subtiliter ramosae, longiore latere marginis interioris areolae exorientes. Spinae solidae tenues spathulatae in costis elevatis juncturae frontis et limbi. Areae porellorum cum porellis rotundis, anulis albis externe circumcinctae. Rimoportula nulla. Fasciae cingulorum apertae, sine foraminibus, pars interior conspicue recedens margine limbi valvae haerens, sine fimbriis. Chloroplasti non visi.

Description: Frustules rectangular in girdle view, forming chains with the aid of spines (Fig. 38). Valves isopolar, elliptical with broadly rounded ends (Figs 27-37). Length 5-7 $\mu \mathrm{m}$, width $4 \mu \mathrm{m}$, 


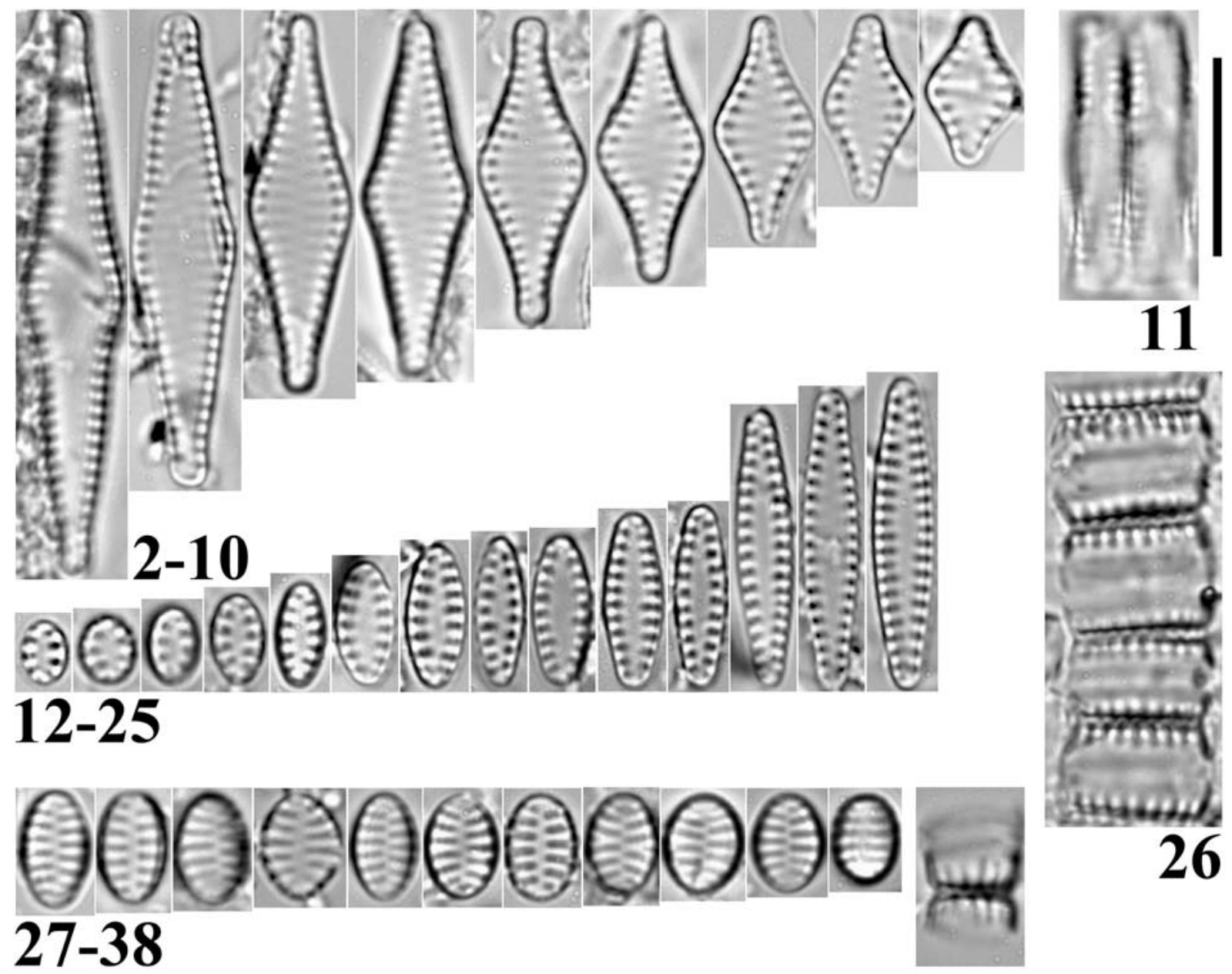

Figs 2-38. LM micrographs of the three taxa described here as new from type material collected from Desaguadero River, Oruro, Bolivia: (2-11) Pseudostaurosira decipiens E. Morales, G. ChÁvez et Ector sp. nov. Figure 11 shows two neighboring frustules in girdle view; (12-26) Pseudostaurosira sajamaensis E. Morales et Ector sp. nov. Figure 26 shows a short chain with frustules in girdle view; (27-38) Staurosira kjotsunarum E. Morales, Novais et Ector sp. nov. Figure 38 shows two neighboring valves still attached. Scale bar $10 \mu \mathrm{m}$.

striae density $14-16$ in $10 \mu \mathrm{m}$. Sternum linear to narrowly lanceolate (Figs 27-37). Mantle steep with edge deeper in central part of the valve than at apices (Figs 57, 60-62). Striae from parallel to radiate, uniseriate and composed of several areolae running continuously from valve face to mantle (Figs 27-37, 57-62). Striae also present in various degrees of development at valve apices underneath the apical pore fields (Figs 57, 58, 6062). Areolae elliptical (apically elongated). Volae finely branched and growing from the longer side of the areolar inner periphery (Figs 57-59, 61, 62). Spines solid, thin, spatulate and located on raised costae at the valve face/mantle junction (Figs 57-62). Apical pore fields present and composed of round poroids, each externally surrounded by whitish rim (Figs 57-62). Rimoportula absent. Girdle bands open, without perforations (Fig. 62). Pars interior of valvocopula conspicuously recessed to accommodate valve mantle edge and without fimbriae (not shown). Plastids not observed.

Holotype: Here designated, permanent slide ANSP GC 26815, Diatom Herbarium, Academy of Natural Sciences, Philadelphia (ANSP).

Isotype: Here designated, permanent slide HCUCB D-0246, Herbario Criptogámico Universidad Católica Boliviana, Cochabamba, Bolivia.

Type locality: Desaguadero River, Department of Oruro, Bolivia, Lat. $17^{\circ} 23^{\prime} 51^{\prime \prime}$, Song. 68 $18^{\circ} 33^{\prime \prime}$ W, 3701 m a.s.l. Collected by G. CHÁVEZ, 07-0509.

Etymology: The term "kotsuña" or "kjotsuñi", used as basis for the species epithet, means "lacustrine men" and refers to the Urus or Uros, a pre-Incan culture older than the Tiahuanaco culture, which developed in the Lake Titicaca area and the banks of the Desaguadero River. 

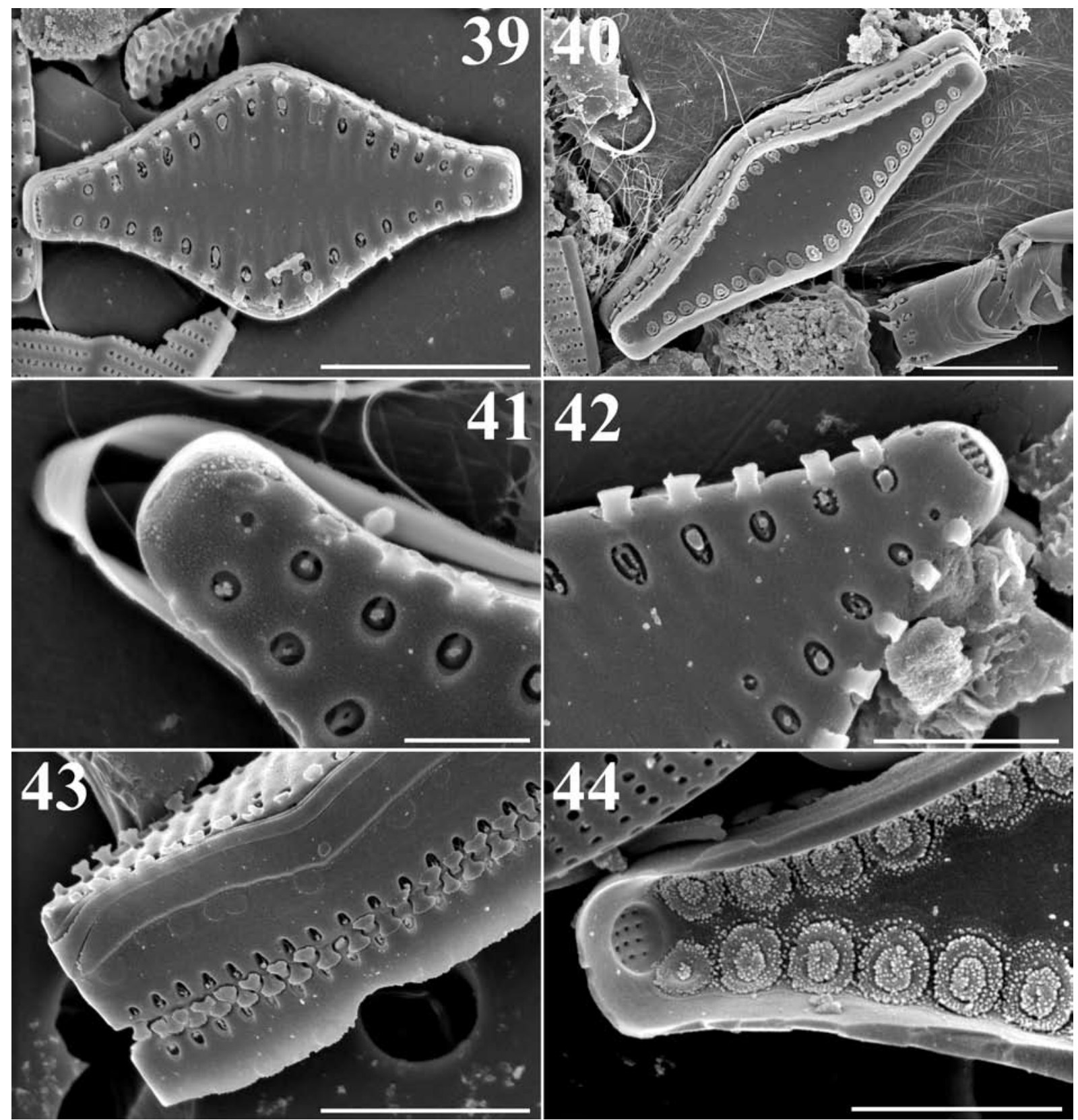

Figs 39-44. SEM micrographs of Pseudostaurosira decipiens E. Morales, G. ChÁvez et ECTOR sp. nov. from type material collected from Desaguadero River, Oruro, Bolivia: (39) overall characteristics of the outer surface of the valve face. Notice an apical pore field on each valve end and striae each predominately composed of one areola; (40) detail of the inner valve surface. Notice superimposed disks formed by depositions of siliceous material on the volae; $(41,42)$ details of valve ends showing position of spatulate spines, occluded (41) and developed (42) apical pore fields, and areolae with accumulation of siliceous material on top of volae; (43) girdle view of a frustule and neighboring valve still attached. Notice blisters or scars along valve mantle edge and open girdle bands. The interlocking, non-ligulate, spatulate spines can also be seen; (44) internal detail of superimposed disks on the areolae and the characteristically sunken apical pore field in a round depression. Scale bars $5 \mu \mathrm{m}$ $(39,40,43) ; 1 \mu \mathrm{m}(41) ; 2 \mu \mathrm{m}(42,44)$.

\section{Discussion}

The presence of several araphid diatoms in the Desaguadero River, two of them abundant in the analyzed sample (Table 1), is in accordance with other studies of fossil and extant diatoms in Altiplanic aquatic ecosystems, which have also shown representatives of Fragilaria, Pseudostaurosira, Staurosira and Staurosirella among the dominant diatom taxa in plankton (e.g., SERVANT-VILDARy 1983), benthos (e.g., ServantVildary 1986; Sylvestre et al. 1996; ServantVILDARY et al. 2002a, b) and tychoplankton (e.g., Sylvestre et al. 2001; Sylvestre 2002; Servant 
Table 1. Count of 500 valves of the sample analyzed for the present manuscript. The species described as new are marked in bold. *Taxa considered as cosmopolitan.

\begin{tabular}{|c|c|c|}
\hline Taxon & No. Valves & Percentage \\
\hline Achnanthidium exiguum (GRUNOW) CZARNECKI* & 73 & 14.6 \\
\hline Achnanthidium minutissimum (KüTZING) CZARNECKI* & 2 & 0.4 \\
\hline Cocconeis placentula var. euglypta (EHRENBERG) GRUNOW* & 23 & 4.6 \\
\hline Denticula valida (Pedicino) Grunow in Van Heurck* & 2 & 0.4 \\
\hline Diadesmis gallica W. Sмгтн* & 12 & 2.4 \\
\hline Epithemia sp. 1 SABAYA & 1 & 0.2 \\
\hline Frankophila similioides LANGE-BERTALOT et RUMRICH & 9 & 1.8 \\
\hline Gomphonema angustatum (KÜTZING) RABENHORST* & 8 & 1.6 \\
\hline Gomphonema cf. parvulum (KÜTZING) KÜTZING & 4 & 0.8 \\
\hline Gomphonema sp. 2 DESAGUADERO & 1 & 0.2 \\
\hline Gomphonema sp. 2 PASORAPILLA & 14 & 2.8 \\
\hline Gomphonema sp. 4 DESAGUADERO & 1 & 0.2 \\
\hline Navicula lauca LANGe-Bertalot et Rumrich & 4 & 0.8 \\
\hline Navicula peregrina (EHRENBERG) KÜTZING & 1 & 0.2 \\
\hline Nitzschia amphibia Grunow* & 1 & 0.2 \\
\hline Nitzschia boliviana E. MoraLES et VIS & 2 & 0.4 \\
\hline Nitzschia cf. vildaryana LANGE-BERTALOT et RUMRICH & 5 & 1 \\
\hline Nitzschia communis RABENHORST* & 1 & 0.2 \\
\hline Nitzschia halloyi MaIDANa et Herbst & 1 & 0.2 \\
\hline Nitzschia microcephala GRUNOw* & 2 & 0.4 \\
\hline Nitzschia valdecostata Lange-Bertalot et Simonsen* & 11 & 2.2 \\
\hline Planothidium rostratum (ØSTRUP) Round et BUKHTIYAROVA* & 2 & 0.4 \\
\hline Planothidium sp. 1 DESAGUADERO & 1 & 0.2 \\
\hline Pseudostaurosira decipiens E. Morales, G. Chávez et ECtor sp. nov. & 3 & 0.6 \\
\hline Pseudostaurosira sajamaensis E. Morales et ECTOR sp. nov. & 256 & 51.2 \\
\hline Pseudostaurosira sp. 2 DESAGUADERO & 25 & 5 \\
\hline Rhopalodia constricta (W. SMItH) KRAMMER* & 1 & 0.2 \\
\hline Rhopalodia sp. 2 DESAGUADERO & 3 & 0.6 \\
\hline Sellaphora sp. 1 DESAGUADERO & 1 & 0.2 \\
\hline Staurosira construens var. binodis (EHRENBERG) P.B. HAMILTON* & 1 & 0.2 \\
\hline Staurosira kjotsunarum E. Morales, Novais et ECTOR sp. nov. & 2 & 0.4 \\
\hline Staurosira sp. 3 DESAGUADERO & 5 & 1 \\
\hline Staurosirella cf. pinnata (EHRENBERG) D.M. Williams et Round & 9 & 1.8 \\
\hline Staurosirella sp. 1 DESAGUADERO & 9 & 1.8 \\
\hline Tabularia sp. 2 DESAGUADERO & 3 & 0.6 \\
\hline Ulnaria sp. 6 DESAGUADERO & 1 & 0.2 \\
\hline TOTAL & 500 & 100 \\
\hline
\end{tabular}

\& Servant-Vildary 2003). It is worth noting that names such as Fragilaria crotonensis KITTON (KitTon 1869), Staurosira construens var. venter (Héribaud) P.B. Hamilton (Hamilton et al. 1992) and Pseudostaurosira subsalina (Hustedt) E. Morales (Morales 2005; Cejudo-Figueiras et al. 2011), which are more common in northern latitudes, pervade fossil and extant species lists presented in publications for the Andes. Type material of these species has not been reanalyzed using modern tools and only iconotypes are available together with their protologues, so it is difficult to assess their original concept and considerable species concept drift may have 


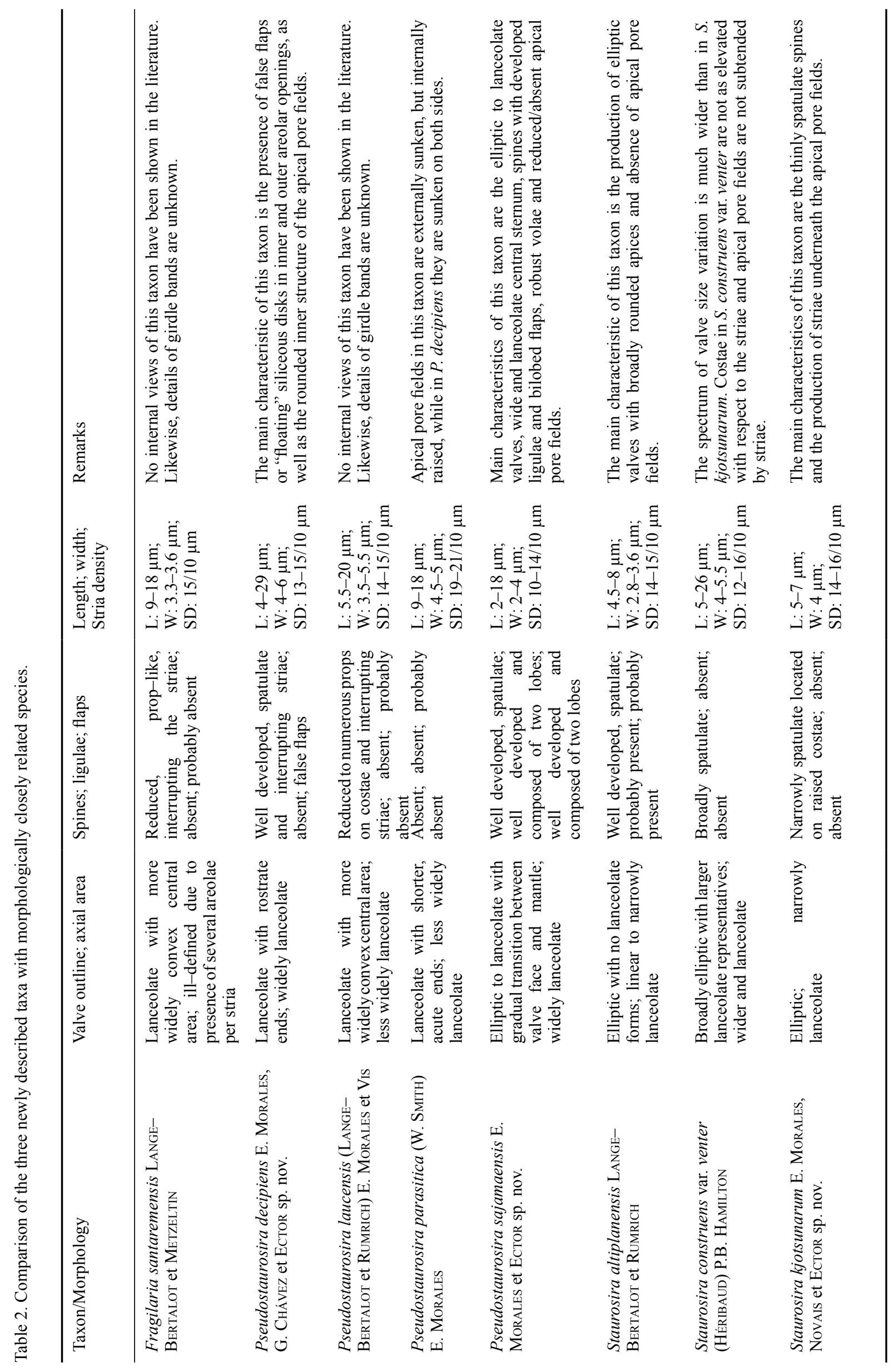



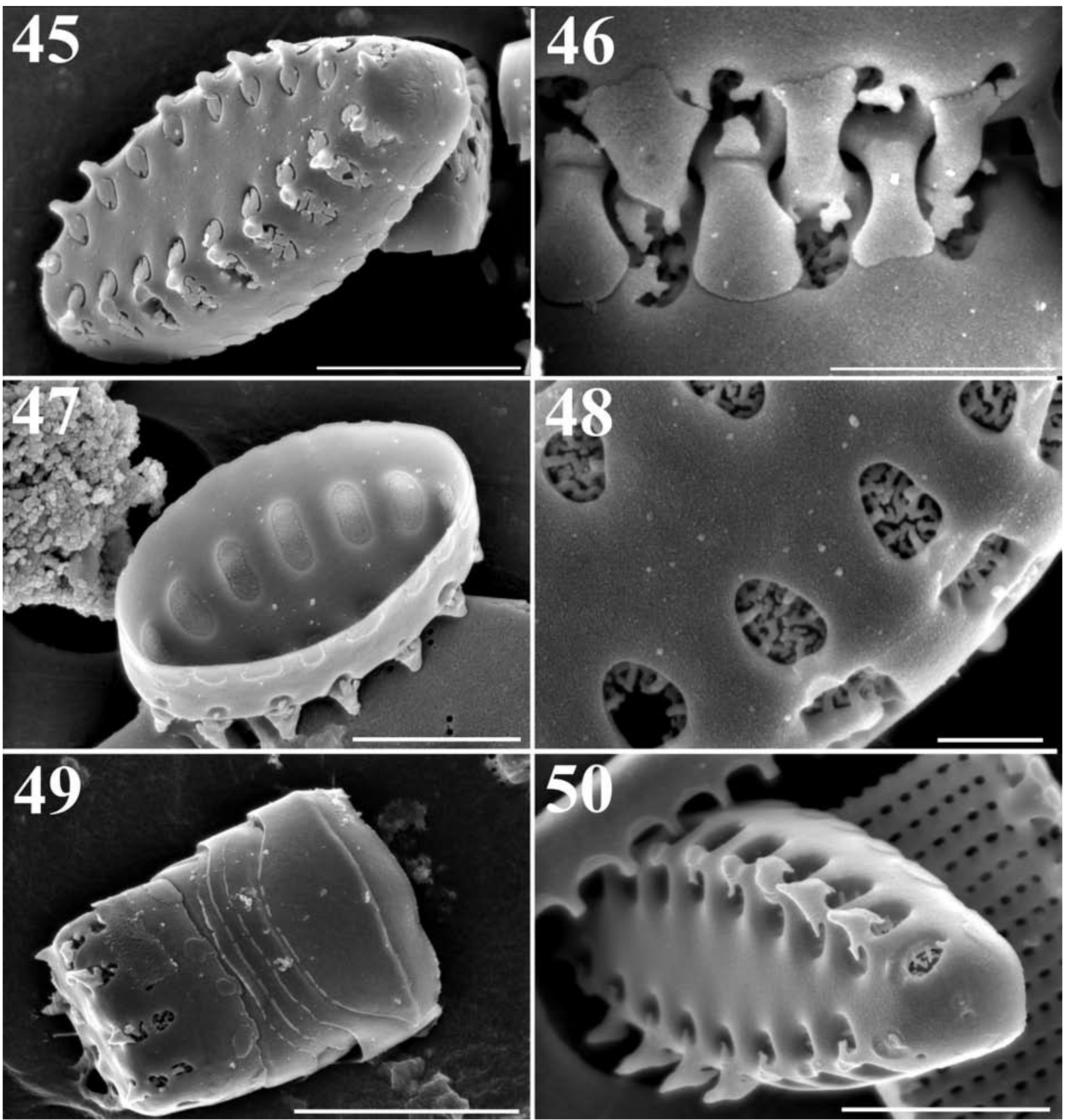

Figs 45-50. SEM micrographs of Pseudostaurosira sajamaensis E. Morales et Ector sp. nov. from type material collected from Desaguadero River, Oruro, Bolivia: (45) tilted valve showing characteristics of the external valve surface and the valve mantle. Notice fully developed ligulae and bilobed flaps covering most of the areolar openings and the position of spines; (46) detail of interlocking spines with developing ligulae; (47) tilted inner view of valve. Notice parallel valve mantle edges and presence of siliceous blisters or scars. Inner opening of the areolae is also covered by a fine siliceous deposition on top of welldeveloped volae; (48) close up on valve outer surface showing profusely grown volae. Spines were broken in this specimen; (49) girdle view of a valve with epi- and hypocingulum. Notice open girdle elements and wider, non-fimbriate valvocopulae with recessed pars interior; (50) detail of apex with occluded apical pore field. Also notice ligulae and flaps developing form the base of each spine onto valve mantle and valve face areolae, respectively. Scale bars $3 \mu \mathrm{m}(45,49) ; 1 \mu \mathrm{m}(46) ; 2 \mu \mathrm{m}(47$, 50); $0.5 \mu \mathrm{m}(48)$.

occurred. A clear example of this drift is the case of Pseudostaurosira elliptica (SCHUMANN) EDLUND, E. Morales et Spaulding, another taxon reported from the Andes (see for example ServantVILDARY 1986, plate 2, figs 21-26), a species whose affinity with the genus Pseudostaurosira (instead of Staurosira as initially thought) was established only after re-examination of type material using a combination of LM and SEM (EDLund et al. 2006). Force-fitting into Europeanbased concepts can not be discarded during identification of Andean material. In this case, 
individuals found in fossil and recent material may have been ascribed names from European floras simply based on gross resemblance and in absence of detailed studies under LM and SEM. A thorough review of the taxonomy presented in publications related to Andean aquatic habitats will have to be performed as more information on type material is produced.

Pseudostaurosira decipiens belongs in the genus Pseudostaurosira since it shares many features with taxa currently ascribed to it. The type of striae and areolae (short striae and wide areolae bearing well-developed volae), the position of the spines (interrupting the striae) and the characteristics of the apical pore fields (ocellulimbus type and sunken into the valve apices) are all features similar to taxa in the $P$. brevistriata sensu lato group. Pseudostaurosira decipiens can be distinguished from other taxa in Pseudostaurosira by the lanceolate shape of the valves with expanded (widely lanceolate) central area, coupled with well-developed spines lacking ligulae, siliceous deposits on outer and inner areolar openings that do not have the same origin as flaps (false flaps) and sit on top of volae, and the inner characteristically rounded structure of the apical pore fields. The lanceolate shape with inflated valve central area is also characteristic of other taxa in Pseudostaurosira or with affinities with this genus. For example, P. parasitica (W. SмIтH) E. Morales (Morales 2003) has this shape, but it has a central area that is more broadly rounded and has shorter, more acute valve ends. In addition, $P$. parasitica lacks spines, does not exhibit the round siliceous deposits found in P. decipiens and the internal structure of the apical pore field is not sunken in internal view as in P. decipiens. Also, Pseudostaurosira laucensis (LANGE-Bertalot et Rumrich) E. Morales et Vis (Rumrich et al. 2000; Morales \& VIS 2007) has valves with lanceolate shape, but the inflated central area is more gently curved (wider convexity), spines are poorly developed and reduced to small numerous props located on costae and interrupting the striae. No internal views or details of striae in $P$. laucensis were presented by RuMrich et al. (2000); thus these structures need further illustration (see Morales \& VIs 2007 for arguments to place this taxon in Pseudostaurosira).

Another taxon with similar shape as that of Pseudostaurosira decipiens is Fragilaria santaremensis Metzeltin et LANGe-Bertalot
(Metzeltin \& Lange-Bertalot 1998), but this taxon has an ill-defined axial area because striae are composed of several areolae located on both sides of the sternum. The spines in $F$. santaremensis are short, prop-like, seem to lack ligulae, and are located at the valve face/ mantle transition interrupting the striae. The ultrastructural information presented by METZELTIN \& Lange-Bertalot (1998) and Rumrich et al. (2000) does not show internal views of the valves on $F$. santaremensis, neither a clear depiction of the volae and structure of the apical pore fields. Based on the SEM outer views presented by these authors, $F$. santaremensis should probably be transferred to Pseudostaurosira, but analysis of type material is recommended before a final decision is made.

Pseudostaurosira pseudoconstruens (MARCINIAK) D.M. Williams et Round (MarciniaK 1982; Williams \& Round 1987) has cruciate valves and thus the inflation of the valve central area is more pronounced than in P. decipiens. Additionally, the spines are located on the costae in P. pseudoconstruens (MARCINIAK 1982; also see Williams \& Round 1987, figs 28-31 under $P$. brevistriata). RUMRICH et al. (2000) report "Staurosira pseudoconstruens (MARCINIAK) nov. comb. prov." from South America (a transfer that has not been made formal to date), on which valves have the spines located along striae and on costae at the same time. Whether these South American populations are different from the one reported by MARCINIAK (1982) from the Tatra Mountains in Poland has to be confirmed by detailed SEM analysis. Nevertheless, the South American populations are different from $P$. decipiens since they have a cruciate shape and the areolae are larger and conspicuous under LM. The disk-like depositions on the outer openings of the areolae are not present in the South American populations, but they seem to be on the inner areolar opening. The apical pore field is round in South American individuals of "Staurosira pseudoconstruens", but they are not sunken into the valve apex to the degree they are in $P$. decipiens.

Pseudostaurosira decipiens had been reported before the present manuscript, but under the name "Fragilaria aff. brevistriata Grunow" (in text) and "Fragilaria brevistriata Grunow" (in plate legend) by Servant-VildDary (1986, plate 3, figs 31b-36). The characteristics of depicted valves are similar to those of $P$. decipiens presented herein; even the characteristic disk-like depositions in the inner 

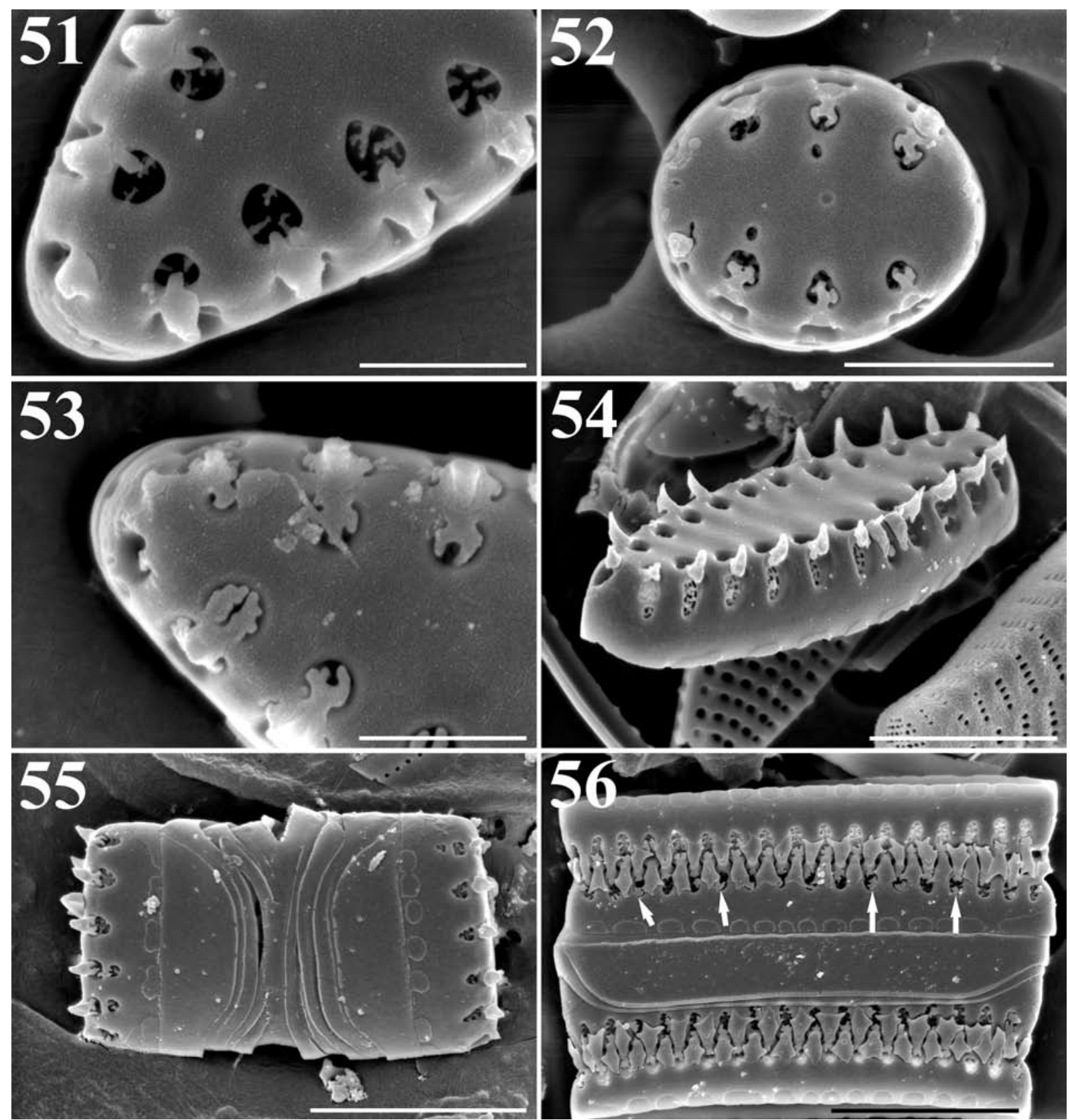

Figs 51-56. SEM micrographs of Pseudostaurosira sajamaensis E. Morales et Ector sp. nov. from type material collected from Desaguadero River, Oruro, Bolivia; this series of micrographs shows a sequence in the development of flaps in valve face areolae (51-53) and ligulae covering the valve mantle areolae (Figs 54-56); (51) Beginning in the growth of flaps at a single or two points at the base of each spine; (52) Elongation and further growth of each flap; (53) Flaps have almost covered the majority of the areolar opening; (54) Beginning in the growth of ligulae from the base of each spine toward the areolar opening immediately beneath them; (55) Left hand side valve shows ligulae that grew from two points along the base of each spine and started to cover each areolar opening; (56) Developed ligulae covering almost entirely areolae at the base of each spine. Also notice higher degree of development in each spine terminus. Arrows indicate flaps developing in sites within the areolae opposite to the origin of the ligulae at the base of the spines. Scale bars $1 \mu \mathrm{m}(51,53) ; 2 \mu \mathrm{m}(52) ; 3 \mu \mathrm{m}(54) ; 4 \mu \mathrm{m}(55) ; 5 \mu \mathrm{m}$ (56).

areolar opening were also shown by SERVANTVILDARY (1986, fig. 36). The range in width $(2-7 \mu \mathrm{m})$ given in the text by SERVANT-VILDARY (1986) for representatives found as epiphytes on aquatic macrophytes from several ponds in the Ichu Khota Valley, also in the Bolivian Altiplano, suggests that several morphological variants may have been lumped into this single category. Lumping was also practiced during identification of material collected from bogs and pond surface sediments from the western Lípez region of the southwestern Bolivian Altiplano as depicted 

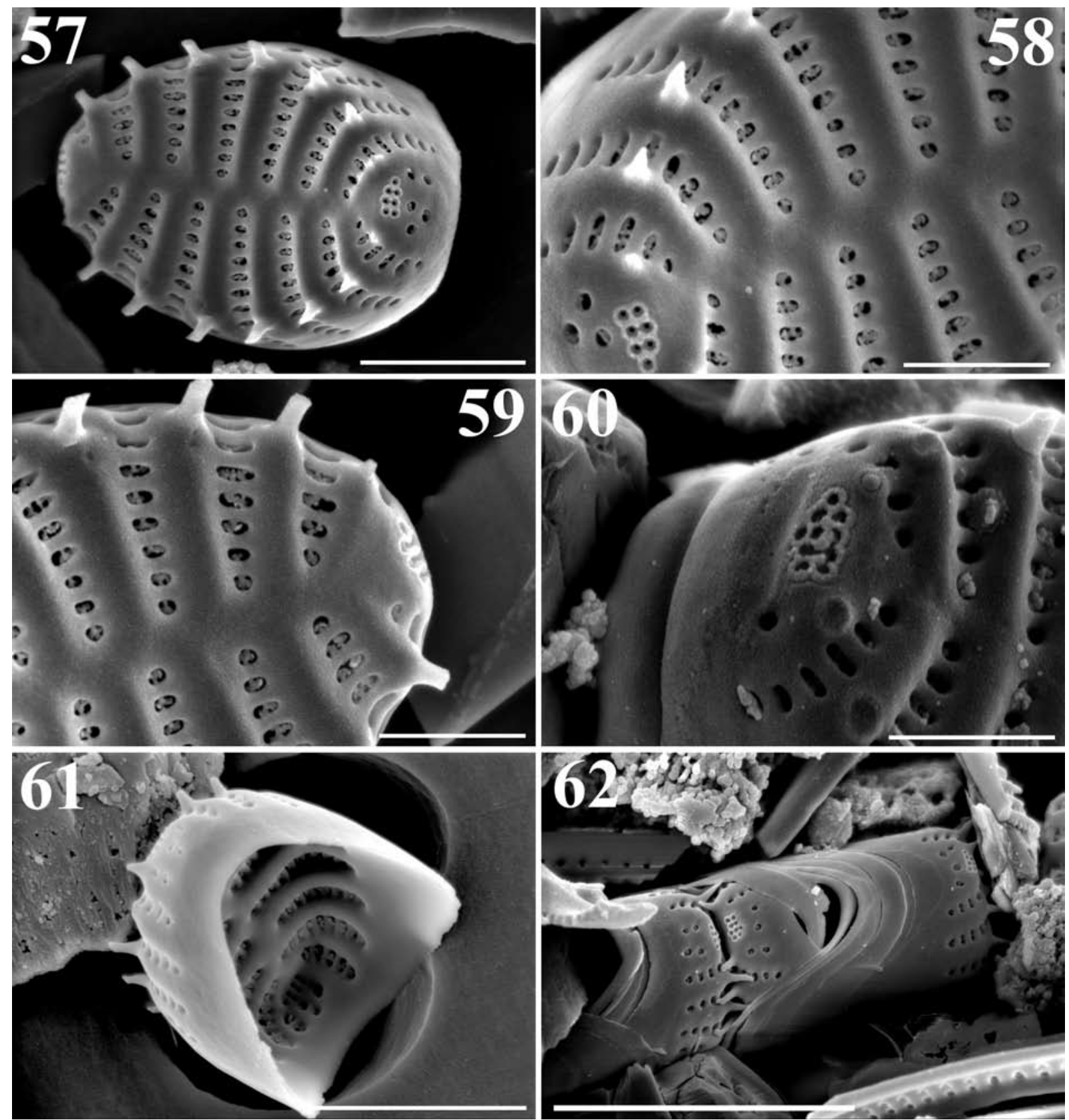

Figs 57-62. SEM micrographs of Staurosira kjotsunarum E. MoralEs, NovaIs et EcTor sp. nov. from type material collected from Desaguadero River, Oruro, Bolivia: (57-59) external details of the same valve. Notice rimmed poroids composing the apical pore fields, the stria composed of round areolae underneath the apical pore field, the transapically elongated areolae bearing finely branched volae composing the striae on valve face and mantle, and the spines located on raised costae; (60) rimmed poroids of apical pore field and broken spines suggesting a solid structure; (61) inner view of striae, raised costae, apical pore fields and subtending striae with round areolae. Also notice shallower valve mantle edge at the valve apices; (62) a frustule and a neighboring valve. Notice open girdle elements, evident in first copulae starting from the right, the slender spines terminating near or over the neighboring valve areolae. Scale bars $2 \mu \mathrm{m}(57) ; 1 \mu \mathrm{m}(58-60) ; 3 \mu \mathrm{m}(61) ; 4 \mu \mathrm{m}(62)$.

by three photographs identified as "Fragilaria brevistriata", each showing a different taxon (SERVANT-VILDARY et al. 2002b). As more populations of altiplanic araphid diatoms are studied in detail, a review of the taxonomy in the cited and additional references will be required, especially because this taxonomy was used as basis for ecological assessments. Works based on fossil diatoms of the Altiplano region would require a similar review.

Pseudostaurosira sajamaensis belongs to the genus Pseudostaurosira because of its short striae, wide areolae, well-developed volae, structure 
and position of spines (well-developed, bearing ligulae and positioned interrupting the striae), and because details of girdle bands (open and with wide valvocopula with recessed pars interior) are closely similar to taxa currently ascribed to this genus. Pseudostaurosira sajamaensis is different from the rest of the taxa in the genus because of its elliptic to lanceolate valve outline, wide central sternum, spines with developed ligulae and bilobed flaps, robust volae and reduced/absent apical pore fields. The flaps in P. sajamaensis are not simple depositions of material as it happens in $P$. decipiens. Instead of floating round structures, the flaps can be seen attached to the base of the spines, where they begin to originate and gradually grow until they cover almost completely the areolar opening. Pseudostaurosira sajamaensis is not the only taxon within Pseudostaurosira to produce flaps. Pseudostaurosira americana E. Morales (Cejudo-Figueiras et al. 2011; also see Morales 2005 under $P$. subsalina (Hustedt) E. Morales) and Pseudostaurosira trainorii E. Morales (Morales 2001) also produce flaps, although they are mostly located on the valve mantle areolae. Figures 51-53 show a sequence in the development of flaps on the valve face of $P$. sajamaensis revealing that growth begins from two points in the areolar inner border near the base of the spines. The two growths meet, forming in a mature state a characteristic "horse track" shaped flap (Fig. 45). Figures 54-56 show the sequence of development of ligulae that eventually cover the outer opening of the mantle areolae located beneath the spines. Growth in this case proceeds also from two points in the spine (near its base) and then the two growths meet to produce a bilobed structure. Flaps can also develop in valve mantle areolae (Fig. 46), but they originate from places in the inner areolar border away from the region near the base of the spine (arrows in Fig. 56). It is uncertain why $P$. sajamaensis would produce such structures in order to almost completely occlude the areolae; this could be a response to the environment that merits further investigation. Staurosira altiplanenis LANGE-BERTALOT et Rumrich (Rumrich et al. 2000) is similar to $P$. sajamaensis. However, valve outline is different in both taxa with $S$. altiplanensis never producing lanceolate forms. The axial area in S. altiplanensis is linear while in P. sajamaensis it is widely lanceolate. Spine ligulae and flaps are probably present in S. altiplanensis (see plate 14, fig. 1, p. 269 in RUMrich et al. 2000), but the protologue does not mention these features and the remaining figures in Rumrich et al. (2000) do not show them. Analysis of type material of $S$. altiplanensis and its subsequent transfer to Pseudostaurosira are recommended. A drift in the concept of $S$. altiplanensis seems to have occurred in the interpretation given to the taxon by MeTzeLtin et al. (2005, plate 15 , figs 10-12). The connection between the LM (fig. 10) and the SEM (figs 11, 12) seems hardly possible based on shape of the valves and characteristics of the axial area. The SEM micrographs conclusively show a taxon with stronger affinities to Staurosira (specifically the $S$. construens var. venter group) based on characteristics of the areolae, apical pore fields and spine position and structure.

The SEM micrograph presented in CABROL et al. (2007, p. 360, fig. 14.5k) identified as $S$. altiplanensis, actually corresponds to $P$. sajamaensis. Although the image is blurry, the elliptic valve shape with acute ends, wide axial area, and the striae formed of only one or two trapezoid areolae on valve face and mantle can be clearly seen.

Pseudostaurosira sajamaensis also appeared photographed in SERVANT-VILDARY \& Roux (1990, p. 276, fig. 27), but was misidentified therein as "Fragilaria brevistriata Grunow". The valve shape, wide axial area, single row of areolae on valve face and mantle, covered by flaps and ligulae, as well as position and appearance of the valve and lack of apical pore fields, all resemble closely the features shown here in Figs 45-56 for P. sajamaensis.

It is possible that the study of type material of additional taxa with affinities to Pseudostaurosira, such as Fragilaria brevistriata var. elliptica HÉRIBAUD, reveal a relationship with $P$. sajamaensis. However, it is currently difficult to establish such a relationship based only on iconotypes and subsequent interpretations in the literature, which may have caused a species concept drift.

The structure of the areolae in both Pseudostaurosira decipiens and P. sajamaensis with disk-like structures covering the outer openings, is reminiscent of species currently placed in the genus Pseudostaurosiropsis (MORALEs 2001, 2002). However, the striking difference among these taxa is that none of the Pseudostaurosiropis representatives produces volae, only the disk-like structure (rota) occluding each areola on both valve face and mantle. Discussion on the evolutionary 
relationship between Pseudostaurosira and Pseudostaurosiropsis taking into account presence/absence of volae and production of flaps is postponed until the type of Pseudostaurosira (P. brevistriata (GRUNOW in VAN HeURCK) D.M. WiLliams et Round) is properly illustrated at the LM and SEM levels and more species within Pseudostaurosiropsis are studied to better approximate variability of this character.

Staurosira kjotsunarum is a representative of Staurosira because it shares characteristics of the striae (small elliptical openings bearing finely branched volae), position and structure of spines (on the costae, solid, thin and spatulate), apical pore fields (composed of a few round poroids each surrounded by a white rim), and girdle bands (open, without perforations, and with valvocopulae having a recessed pars interior) with taxa currently allocated to this genus. Staurosira kjotsunarum is different from other species in the genus because it has elevated costae on both external and internal views, narrowly spatulate spines that accomplish colony formation by holding onto neighboring valve areolae, and produces striae composed of round poroids beneath the apical pore fields (instead of the regular apically elongated areolae sitting on valve face and rest of the mantle).

Staurosira dimorpha E. Morales, Spaulding et Edlund (Morales et al. 2010) has valve outline and a general appearance similar to S. kjotsunarum. However, S. dimorpha produces spines facultatively and has two rows of small poroids separated by a hyaline ridge on the abvalvar edge of the girdle elements. All valves of Staurosira kjotsunarum found during SEM analysis of Desaguadero River material had spines always present and no poroids on the girdle elements.

Smaller, elliptical representatives of Staurosira construens var. venter (НАMILTON et al. 1992; Morales 2010) could be confused with S. kjotsunarum under LM. However, valves of the var. venter are broadly elliptical (they are somewhat inflated at the valve center) and frequently have a wider axial area. At the SEM level, the var. venter produces broadly spatulate spines (with enlarged ends that interlock securing neighboring valves) instead of narrowly spatulate, costae are less elevated (in internal and external views), and the striae do not continue under the apical pore fields as it happens in S. kjotsunarum. Also, it must be noted that $S$. construens var. venter produces large individuals with lanceolate valves with rostrate ends; such a valve outline has not been observed in S. kjotsunarum.

Staurosira elliptica (Schumann) Cleve et Möller sensu Morales (Morales 2001) also produces small elliptical valves that could potentially be confused with $S$. kjotsunarum. However, the taxon in Morales (2001) produces small valves that tend to be round instead of elliptical, has smaller areolae composing the striae; furthermore, spines are broadly spatulate, the apical pore fields are less developed, and striae are not produced underneath the apical pore fields. The taxon in Morales (2001, fig. 2a-d) is currently orphan since the study of type material of Fragilaria elliptica SCHUMANN and subsequent transfer to the genus Pseudostaurosira (SCHUMANN 1867; EdLund et al. 2006). The taxon in Morales (2001) clearly belongs in Staurosira, but additional ultrastructural details are needed to describe it as a new taxon.

Of the 228 taxa found during the study, only 37 $(16.2 \%)$ are considered as cosmopolitan and from these only 13 appeared during the 500 valve count (Table 1). A complete list of taxa found in the Desaguadero River sample will be presented in a subsequent publication covering the entire flora found at this site. Several localities in the Altiplano sampled by the senior author contain a similar richness and the high proportion of unknown taxa and low proportion of known cosmopolitans are a characteristic of these samples, as well. Taxonomic data of the samples will be published later and after combination of rigorous LM and SEM analyses. The Desaguadero River sample and the others currently under study come from relatively undisturbed areas of the Altiplano or areas with little human influence. Thus, it is possible that the current view that the Andean flora is characterized by relatively few endemic elements and a high proportion of cosmopolitan taxa (Rumrich et al. 2000; Metzeltin \& LangeBERTALOT 2007), changes very quickly as more of these pristine to semi-pristine localities are sampled. This expectation is here corroborated by the facts that $53 \%$ of the taxa recorded during the present study could not be identified using all available literature and that for the 47 recorded genera approximately $60 \%$ of them contained at least one undetermined taxon. Additionally, the richness of the Andean flora could be much higher than expected. The 228 taxa found in the Desaguadero River sample represent $25 \%$ of the 
888 taxa recorded in RUMRICH et al. (2000) based on 350 samples.

\section{Acknowledgements}

We thank Dr. Francis R. Trainor (The University of Connecticut, Storrs, USA) for reviewing the manuscript and Dr. Saúl Blanco (University of León, Spain) and Dr. Petr Marvan (Botanický ústav AV, Czeck Republic) for translation of the protologues into Latin and advice on ICBN rules. EAM is indebted to Dr. Andrzej Witkowski (University of Szczecin, Poland), Dr. Donald F. Charles (The Academy of Natural Sciences of Philadelphia), and the Public Research Centre - Gabriel Lippmann, Luxembourg for making possible a research trip to Europe to study in part the material presented in this manuscript.

\section{References}

AnONYMous (1975): Proposal for standardization of diatom terminology and diagnoses. - Nova Hedwigia, Beiheft 53: 323-354.

Barber, H.G. \& Haworth, E.Y. (1981): A guide to the morphology of the diatom frustule with a key to the British freshwater genera. - Freshwater Biological Association Scientific Publication 44: 1-112.

Cabrol, N.A.; McKay, C.P.; Grin, E.A.; Kiss, K.T.; Ács, E.; Tóth, B.; Grigorszky, I.; Szabò, K.; Fike, D.A.; Hock, A.N.; Demergasso, C.; Escudero, L.; Galleguillos, P.; Chong, G.; Grigsby, B.H.; Róman J.Z. \& TAMBLEY, C. (2007): Signatures of habitats and life in Earth's high-altitude lakes: clues to Noachian aqueous environments on Mars. - In: ChAPMAN, M. (ed.): The Geology of Mars: Evidence from Earth-Based Analogs. - pp. 349-370, Cambridge University Press, Cambridge.

Cejudo-Figueiras, C.; Morales, E.A.; Wetzel, C.E.; Blanco, S.; Hoffmann, L. \& Ector, L. (2011): Analysis of the type of Fragilaria construens var. subsalina (Bacillariophyceae) and description of two morphologically related taxa from Europe and the United States. - Phycologia 50: 67-77.

Cruces, F.; Urrutia, R.; Parra, O.; Araneda, A.; Treutler, H., Bertrand, S.; Fagel, N.; Torres, L.; Barra, R. \& Chirinos, L. (2006): Changes in diatom assemblages in an Andean lake in response to a recent volcanic event. - Archiv für Hydrobiologie 165: 23-35.

Edlund, M.B.; Morales, E.A. \& Spaulding, S.A. (2006): The type and taxonomy of Fragilaria elliptica Schumann, a widely misconstrued taxon. - In: WitKowsKi, A. (ed.): Proceedings of the Eighteenth International Diatom Symposium, Miedzyzdroje, Poland, 2nd-7th September 2004. - pp. 53-59, Biopress Limited, Bristol.

Frenguelli, J. (1939): Diatomeas del Lago Titicaca. - Notas del Museo de La Plata Tomo IV, Botánica 24: 175198.
Hamilton, P.B.; Poulin, M.; Charles, D.F. \& Angell, M. (1992): Americanarum Diatomarum Exsiccata: CANA, voucher slides from eight acidic lakes in Northeastern North America. - Diatom Research 7: $25-36$.

Hofmann, G.; Werum, M. \& Lange-Bertalot, H. (2011): Diatomeen im Süßwasser-Benthos von Mitteleuropa. Bestimmungsflora Kieselalgen für die ökologische Praxis. Über 700 der häufigsten Arten und ihre Ökologie. - 908 pp., A.R.G. Gantner Verlag K.G., Ruggell.

Hohn, M.H. (1966): Bacillariophyta. - In: Patrick, R.; Aldrich, F.A.; Cairns, J.JR.; Drouet, F.; Hohn, M.H.; Roback, S.S.; Skuja, H.; Spanger, P.J.; Swabey, Y.H. $\&$ WhitFord, L.A. (eds): The Catherwood Foundation Peruvian-Amazon expedition: limnological and systematic studies. - Monographs of the Academy of Natural Sciences of Philadelphia 14: 459-495.

IBISCH, P. \& MeridA, G. (2003): Biodiversidad: La riqueza de Bolivia. Estado del conocimiento y conservación. 638 pp., Editorial Fundación Amigos de la Naturaleza (FAN), Santa Cruz, Bolivia.

ILtis, A. (1993): Recent limnological changes in a saline lake of the Bolivian Altiplano, Lake Poopo. - International Journal of Salt Lake Research 2: 17-28.

Kitton, F. (1869): Notes on New York diatoms with description of a new species Fragilaria crotonensis. Hardwicke's Science-Gossip 5: 109-110.

Kociolek, J. \& Spaulding, S.A. (2000): Freshwater diatom biogeography. - Nova Hedwigia 71: 223-241.

Krammer, K. (1997a): Die cymbelloiden Diatomeen. Eine Monographie der weltweit bekannten Taxa. Teill. Allgemeines und Encyonema Part. - Bibliotheca Diatomologica 36: 1-382.

Krammer, K. (1997b): Die cymbelloiden Diatomeen. Eine Monographie der weltweit bekannten Taxa. Teil 2. Encyonema part., Encyonopsis und Cymbellopsis. Bibliotheca Diatomologica 37: 1-469.

Krammer, K. (2000): The genus Pinnularia. - In: LangeBertalot, H. (ed.): Diatoms of Europe. Diatoms of the European inland waters and comparable habitats 1. -703 pp., A.R.G. Gantner Verlag, Ruggell.

Krammer, K. \& Lange-Bertalot, H. (1986): Bacillariophyceae 1: Naviculaceae. - In: EtTL, H.; Gerloff, J.; Heynig, H. \& Mollenhauer, D. (eds): Süsswasserflora von Mitteleuropa 2/1. - 876 pp., Gustav Fisher Verlag, Stuttgart.

Krammer, K. \& Lange-Bertalot, H. (1988): Bacillariophyceae 2: Bacillariaceae, Epithemiaceae, Surirellaceae. - In: Ettl, H.; Gerloff, J.; Heynig, H. \& Mollenhauer, D. (eds): Süsswasserflora von Mitteleuropa 2/2. - 596 pp., Gustav Fisher Verlag, Stuttgart.

Krammer, K. \& Lange-Bertalot, H. (1991a): Bacillariophyceae 3: Centrales, Fragilariaceae, Eunotiaceae. - In: Ettl, H.; Gerloff, J.; Heynig, H. \& Mollenhauer, D. (eds): Süsswasserflora von Mitteleuropa 2/3. - 576 pp., Gustav Fisher Verlag, 
Stuttgart.

Krammer, K. \& Lange-Bertalot, H. (1991b): Bacillariophyceae 4: Achnanthaceae. Kritische Ergänzungen zu Navicula (Lineolatae) und Gomphonema. - In: Ettl, H.; Gärtner, G.; Gerloff, J.; Heynig, H. \& Mollenhauer, D. (eds): Süsswasserflora von Mitteleuropa 2/4. - 437 pp., Gustav Fisher Verlag, Stuttgart.

Lange-Bertalot, H. (1993): 85 Neue Taxa und über 100 weitere neu definierte Taxa ergänzend zur Süßwasserflora von Mitteleuropa 2/1-4.-Bibliotheca Diatomologica 27: 1-454.

Lange-Bertalot, H. (2001): Navicula sensu stricto, 10 genera separated from Navicula sensu lato, Frustulia. - In: LANGe-Bertalot, H. (ed.): Diatoms of Europe. Diatoms of the European inland waters and comparable habitats 2. -256 pp., A.R.G. Gantner Verlag K.G., Ruggell.

Lange-Bertalot, H. \& Metzeltin, D. (2009): A dystrophic mountain lake in Panama - Hot spot of new and rare neotropical diatoms. - Nova Hedwigia, Beiheft 135: 137-166.

MacDougall, A. \& Turkington, R. (2005): Are invasive species the drivers or passengers of change in degraded ecosystems? - Ecology 86: 42-55.

Manguin, E. (1964): Contribution à la connaissance des diatomées des Andes du Pérou. - Mémoires du Muséum d'Histoire Naturelle, Série B, Botanique 12: 41-98.

MARCINIAK, B. (1982): Late glacial and Holocene new diatoms from a glacial Lake Przedni Staw in the Piec Stawów Polskich Valley, Polish Tatra Mts. - Acta Geologica Academiae Scientiarum Hungaricae 25: 161-171.

Metzeltin, D. \& Lange-Bertalot, H. (1998): Tropical diatoms of South America I. About 700 predominantly rarely known or new taxa representative of the neotropical flora. - Iconographia Diatomologica 5: $1-695$.

Metzeltin, D. \& Lange-Bertalot, H. (2007): Tropical diatoms of South America II. Special remarks on biogeographic disjunction. - Iconographia Diatomologica 18: 1-877.

Metzeltin, D.; Lange-Bertalot, H. \& García-Rodríguez, F. (2005): Diatoms of Uruguay compared with other taxa from South America and elsewhere. Iconographia Diatomologica 15: 1-736.

Morales, E.A. (2001): Morphological studies in selected fragilarioid diatoms (Bacillariophyceae) from Connecticut waters (U.S.A.). - Proceedings of the Academy of Natural Sciences of Philadelphia 151: $105-120$.

Morales, E.A. (2002): Studies in selected fragilarioid diatoms of potential indicator value from Florida (USA) with notes on the genus Opephora Petit (Bacillariophyceae). - Limnologica 32: 102-113.

Morales, E.A. (2003): On the taxonomic status of the genera Belonastrum and Synedrella proposed by Round and Maidana (2001). - Cryptogamie, Algologie 24:
$277-288$.

Morales, E.A. (2005): Observations of the morphology of some known and new fragilarioid diatoms (Bacillariophyceae) from rivers in the USA. Phycological Research 53: 113-133.

Morales, E. (2010). Staurosira construens. - In: Diatoms of the United States. http://westerndiatoms.colorado. edu/taxa/species/staurosira_construens_var._venter (Accessed May 4, 2011).

Morales, E.A. \& VIS, M.L. (2007): Epilithic diatoms (Bacillariophyceae) from cloud forest and alpine streams in Bolivia, South America. - Proceedings of the Academy of Natural Sciences of Philadelphia 156: 123-155.

Morales, E.A.; Edlund, M.B. \& Spaulding, S.A. (2010): Description and ultrastructure of araphid diatom species (Bacillariophyceae) morphologically similar to Pseudostaurosira elliptica (Schumann) Edlund et al. - Phycological Research 58: 97-107.

Morales, E.A.; Vis, M.L.; Fernández, E. \& KocioleK, J.P. (2007): Epilithic diatoms (Bacillariophyta) from cloud forest and alpine streams in Bolivia, South America 2: A preliminary report on the diatoms from Sorata, Department of La Paz. - Acta Nova 3: 680696.

Morales, E.A.; Fernández, E.; Fernandez, C.E.; Lizarro, D. \& AlcorezA, P. (2008): Algal studies in Bolivia, a compilation and preliminary analysis of the existing phycological literature. - Gayana Botánica 65: 93109.

Navarro, G. \& Maldonado, M. (2004): Geografía ecológica de Bolivia. Vegetación y ambientes acuáticos. - 719 pp., Centro de Ecología Simón I. PatiñoDepartamento de Difusión. Santa Cruz, Bolivia.

PAtrick, R. (1961): Diatoms (Bacillariophyceae) from the alimentary tract of Phoenicoparrus jamesi (sclater). - Postilla, Yale Peabody Museum of Natural History 49: 43-56.

Patrick, R. \& Reimer, C.W. (1966): The diatoms of the United States exclusive of Alaska and Hawaii. Vol. 1. Fragilariaceae, Eunotiaceae, Achnanthaceae, Naviculaceae. - Monographs of the Academy of Natural Sciences of Philadelphia 13: 1-688.

Patrick, R. \& Reimer, C.W. (1975): The diatoms of the United States exclusive of Alaska and Hawaii. Vol. 2, Part 1. Entomoeidaceae, Cymbellaceae, Gomphonemaceae, Epithemiaceae. - Monographs of the Academy of Natural Sciences of Philadelphia 14: 1-213.

Rigsby, C.A.; Bradbury, J.P.; Baker, P.A.; Stephanie, M.R. \& WARREN, M.R. (2005): Late Quaternary palaeolakes, rivers, and wetlands on the Bolivian Altiplano and their palaeoclimatic implications. - Journal of Quaternary Research 20: 671-691.

Ross, R.; Cox, E.J.; Karayeva, N.I.; Mann, D.G.; Paddock, T.B.B.; Simonsen, R. \& Sims, P.A. (1979): An amended terminology for the siliceous components of the diatom cell. - Nova Hedwigia, Beiheft 64: 513-533. 
Round, F.E.; Crawford, R.M. \& Mann, D.G. (1990): The Diatoms: Biology and Morphology of the Genera. 747 pp., Cambridge University Press, Cambridge.

Rumrich, U.; Lange-Bertalot, H. \& Rumrich M. (2000): Diatoms of the Andes: from Venezuela to Patagonia/ Tierra del Fuego. - Iconographia Diatomologica 9: $1-649$.

Schumann, J. (1867): Preussische Diatomeen. - Schriften der Königlichen Physikalisch-Ökonomischen Gesellschaft zu Königsberg 8: 37-68.

Servant, M. \& Servant-Vildary, S. (2003): Holocene precipitation and atmospheric changes inferred from river paleowetlands in the Bolivian Andes. Palaeogeography, Palaeoclimatology, Palaeoecology 194: 187-206.

Servant-Vildary, S. (1978a): Les diatomées des dépôts lacustres quaternaires de l'Altiplano bolivien. Cahiers O.R.S.T.O.M., Série Géologie 10: 25-35.

Servant-VILDARy, S. (1978b): Les diatomées des sédiments superficiels d'un lac salé, chloruré, sulfaté sodique de l'Altiplano bolivien, le lac Poopó. - Cahiers O.R.S.T.O.M., Série Géologique 10: 79-90.

Servant-Vildary, S. (1983): Les diatomées des sédiments superficiels de quelques lacs salés de Bolivie. Sciences Géologiques, Bulletin 36: 249-253.

Servant-Vildary, S. (1986): Les diatomées actuelles des Andes de Bolivie (Taxonomie, écologie). - Cahiers de Micropaléontologie 1: 99-124.

Servant-Vildary, S. (1992): VI.1. Phytoplankton. VI.1a. The diatoms. - In: Dejoux, C. \& Iltis, A. (eds): Lake Titicaca: A synthesis of limnological knowledge. Monographiae Biologicae 68. - pp. 163-175, Kluwer Academic Publishers, Dordrecht.

Servant-Vildary，S. \& Roux, M. (1990): Multivariate analysis of diatoms and water chemistry in Bolivian saline lakes. - Hydrobiologia 197: 267-290.

Servant-Vildary, S.; Risacher, F. \& Roux, M. (2002a): Diatom based transfer function for estimating the chemical composition of fossil water. Calibration based on salt lakes of the Lipez area in the southwestern Bolivian Altiplano. - Carnets de Géologie / Notebooks on Geology - Memoir 2002/01 (CG2002_M01): 1-11.

Servant-Vildary, S.; Risacher, F.; Roux, M.; Landre, J. \& Cornée, A. (2002b): Les diatomées des milieux salés (Ouest-Lipez, SW de l'Altiplano bolivien). -http://www.mnhn.fr/mnhn/geo/diatoms/index.htm (Accessed May 3, 2011).

Simonsen, R. (1987): Atlas and catalogue of the diatom types of Friedrich Hustedt. - Vol. 1, Calatogue, 525 pp.; Vol. 2, Atlas, Plates 1-395, 597 pp.; Vol. 3, Atlas, Plates 396-772, 619 pp., J. Cramer, Berlin-Stuttgart.

Sylvestre, F. (2002): A high-resolution diatom reconstruction between 21,000 and $17,000{ }^{14} \mathrm{C}$ yr $\mathrm{BP}$ from the southern Bolivian Altiplano $\left(18-23^{\circ} \mathrm{S}\right)$. - Journal of Paleolimnology 27: 45-57.

Sylvestre, F.; Servant-Vildary, S. \& Roux, M. (2001): Diatom-based ionic concentration and salinity models from the south Bolivian Altiplano $\left(15-23^{\circ} \mathrm{S}\right)$. - Journal of Paleolimnology 25: 279-295.

Sylvestre, F.; Servant-Vildary, S.; Fournier, M. \& Servant, M. (1996). Lake levels in the southern Bolivian Altiplano $\left(19^{\circ}-21^{\circ} \mathrm{S}\right.$.) during the Late Glacial based on diatom studies. - International Journal of Salt Lake Research 4: 281-300.

Sylvestre, F.; Servant, M.; Servant-Vildary, S.; Causse, C.; Fournier, M. \& YBert, J.-P. (1999): Lake-level chronology on the Southern Bolivian Altiplano $\left(18^{\circ}-23^{\circ} \mathrm{S}\right)$ during late-glacial time and the early Holocene. - Quaternary Research 51: 54-66.

TAPIA, P.M.; FritZ, S.C.; BAKER, P.A.; SEltZer, G.O.\& DunBAR, R.B. (2003): A Late Quaternary diatom record of tropical climatic history from Lake Titicaca (Peru and Bolivia). - Palaeogeography, Palaeoclimatology, Palaeoecology 194: 139-164.

VAn DE ViJver, B. \& CocQuyt, C. (2009): Four new diatom species from la Calera hot spring in the Peruvian Andes (Colca Canyon). - Diatom Research 24: 209223.

Vanormelingen, P.; Verleyen, E. \& Vyverman, W. (2008): The diversity and distribution of diatoms: from cosmopolitanism to narrow endemism. - Biodiversity and Conservation 17: 393-405.

Williams, D.M. \& Round, F.E. (1987): Revision of the genus Fragilaria. - Diatom Research 2: 267-288.

(C) Czech Phycological Society (2012)

Received May 5, 2011

Accepted August 3, 2011 